\title{
INCLUSIVE INSTRUCTION: BLURRING DIVERSITY AND DISABILITY IN LAW SCHOOL CLASSROOMS THROUGH UNIVERSAL DESIGN
}

\author{
Meredith George* and Wendy Newby ${ }^{* *}$
}

This Article addresses the difficult issues faced by law schools in determining the use of accommodations for students with disabilities in the context of the Americans with Disabilities Act of $1990^{1}$ (ADA) and, in particular, for those with "invisible disabilities," such as learning disabilities, emotional disabilities, and attention disorders. Because the manner in which accommodations are delivered is specific for each university and factintensive for each student, there often is confusion about the role played by accommodations in supporting an educational process while providing equal access in academic environments as mandated by the ADA. We suggest an alternative to the exclusive use of accommodations as the vehicle through which access is attained. We argue that law schools should adopt Universal Design for Instruction (UDI) principles as the foundation of pedagogical practice in law school classrooms and for assessment of learning outcomes. Changes based on these principles have the potential to provide access for students with disabilities without altering the essential nature of the curriculum and program objectives.

When Congress passed the ADA in 1990, building on the rights accorded to individuals with disabilities in the Rehabilitation Act of $1973,{ }^{2}$ it did so to grant full civil rights to individuals with disabilities by providing access to places and programs that might have been inaccessible to them in the past. The aspirational goals of the ADA were to allow individuals with significant disadvantages to enter and sustain their productivity in the workplace and, in academic settings, to prepare for a future of work as productive and independent citizens.

\footnotetext{
* Associate, Arnold \& Porter, LLP, Washington, D.C.; B.A., University of North Carolina at Chapel Hill, 2002; J.D., Emory University School of Law, 2006. The ideas expressed in this Article are the authors' and do not reflect the views of any client.

** Associate Dean, Emory College and Director of Faculty Resources for Inclusive Instruction, Emory University; B.S., Cornell University, 1965; M.Ed. NC State University, 1976; Ph.D in Psychology, NC State University, 1996.

1. $\quad 42$ U.S.C. $\S \S 12101-12213(2000)$.

2. 29 U.S.C.A. $\S \S 791,793-794$ (West 1999 \& Supp. 2002).
} 
The application of the ADA has proved difficult, however. The language of the Act provides direction without clarity by loosely defining disability as a "substantial limitation in a major life activity." This amorphous definition leaves to the courts the task to delineate who is disabled. While the ADA further provides that a person who is substantially limited should receive reasonable accommodation, the Act's language fails to describe the parameters of what is reasonable and what specific remedies or "reasonable accommodations" should be considered to allow the individual full access to the same opportunities that a non-disabled individual would have. ${ }^{4}$ The Act instead gives only basic guidelines. These guidelines result in considerable variance in processes, procedures, and uses of accommodations granted to students, thus raising concerns, particularly in professional schools, about the competence to perform the essential functions of the job by those who have received accommodations.

Assessing the extent and impact of non-visible disabilities is considerably more complex than determining the limitations caused by more visible disabilities such as sensory and mobility impairments. There are many factors to consider in determining whether a person is "significantly limited" based on disability, including measurable deficits, the manner in which the individual has adjusted to the limitation, and the environment in which the individual is expected to function. Clinical judgment varies, however, when considering the negative effect of an auditory processing disorder that underlies a learning disability as compared to a hearing disorder that limits the input or organization of sound. Here is where the fields of law, psychology, and education intersect and can benefit from a conversation to promote understanding. In this Article, we, as a psychologist and a lawyer, look over the landscape of the ADA in the law school setting and the interpretation of the Act by the courts, and examine some case studies that present particular difficulties for determining how to provide "access" without overaccommodating or providing an undue advantage to an individual with a disability. Some new approaches to pedagogy will be explored in light of their potential to decrease the need for "accommodations" and to replace these with instructional approaches that are designed to address diversity in the classroom.

3. 42 U.S.C. $\S 12102(2)$.

4. Id. $\S 12111(9)$. 


\section{The Issue}

The ADA has obvious effects: it allows more people to enter into work and educational settings and leads to a more productive and less dependent work force, thus empowering a segment of the population that is disadvantaged and increasing the economic value of the individual to the society.

Since the passage of the Act, controversy has erupted around its implementation-who should get accommodations, how accommodations should be determined, and what type of accommodations are deserved. The number of students seeking accommodations and filing claims rose dramatically after the Act was passed. ${ }^{5}$ Approximately $9 \%$ of all undergraduates reported having a disability, with the most common disabilities being orthopedic or mobility impairments (29\%), mental illness or depression $(17 \%)$, health impairments $(15 \%)$, visual or hearing impairments $(12 \%)$, learning disabilities or attention deficit disorders (11\%), and other disabilities $(15 \%) .{ }^{6}$ Students with learning or attention disabilities reported higher levels of accommodations (51\%) compared with those with other disabilities (19-30\%). ${ }^{7}$ It is not surprising, therefore, that students who have received accommodations based on their disabilities have opportunities to be successful and to advance to graduate programs. Still, only "qualified" individuals who can perform the "essential functions" of the position or program are considered for accommodations under the ADA. ${ }^{8}$ Thus, if the employee or student cannot meet the standards established for the job or program with a "reasonable" accommodation, there is no cause for circumvention of the standards. The questions then raised are what is "essential" in the job or program and just who is qualified. To comply with the ADA, law schools must determine what is essential to their programs. ${ }^{9}$

5. See, e.g., Tracey I. Levy, Legal Obligations and Workplace Implications of Higher Education Accommodating Learning Disabled Students, 30 J.L. \& Educ. 85, 85-86 (2001). Levy reports that between 1992 and 1993, students seeking accommodations for learning disabilities on the New York Bar Exam grew two-fold, while applications to Boston University from students classifying themselves as having a learning disability "increased ten-fold between 1990-1995." Id.

6. John Wirt et Al., U.S. Dep't of Educ., The Condition of Education 68 (NCES 2003-067, 2003), available at $\mathrm{http} / / / \mathrm{nces} . \mathrm{ed} . \mathrm{gov} / \mathrm{pubs} 2003 / 2003067$.pdf.

7. Id.

8. See §12111(8); see also, e.g., Amir v. St. Louis Univ., 184 F.3d 1017, 1028-29 (8th Cir. 1999).

9. As was noted at the Symposium, this determination by law schools is incomplete at best. Medical schools, on the other hand, have done a much better job of determining the essential functions of 
As stated above, one who is disabled has a substantial limitation in a major life activity. ${ }^{10}$ The ADA provision least likely to cause concern to educators, administrators, and students affects the determination of whether an individual is disadvantaged in performing a "major life activity" when the student has a visible disability. The classification of visible disabilities such as hearing, seeing, breathing, walking, and other sensory and motor impairments, leaves little to debate insofar as these impairments obviously affect major life activities.

The documentation provided to universities by professionals can quantify the degree to which a student is mobility, hearing, or visually impaired and thus can suggest remedies to accommodate these individuals. Many of these individuals have lived a life with an observable (visible) disability and have developed a full range of adaptive capabilities that have led to their success, ultimately allowing them entrance to the work or school setting. These individuals enter programs and workplaces with the technologies they need to fully participate therein. They require logistical support, such as audio enhancement, real-time captioning, or an accessible entrance to the space. For the most part, peers and educators accept the disability as one that requires accommodation. Issues of "fairness" do not arise because society intuitively grants that the individual is "disabled" even though it may not understand the total impact of the disability.

Issues arise, however, in the categories of "major life activities" of working and learning. Mental impairments include a broad range of issues whose impacts are not easily defined or measured. ${ }^{11}$ While documentation may be provided to the university, questions still arise in the implementation of accommodations for those with non-visible disabilities. It is easy to find the justification in granting someone with a visual impairment an electronic or human "reader" for an examination. Is it equally valid to provide this accommodation for an individual with a visual processing disorder that results in a slower-than-average reading speed? One can certainly make the case for allowing extended time or an amanuensis on a test for an individual with a motor impairment, such as cerebral palsy, that affects output in writing, but would the same argument apply to an individual with a significant attention

their programs. See Jennifer E. Watson \& Shannon H. Hutchens, Ass'n of Am. Med. Colls., Medical Students with Disabilities: A Generation of Practice (2005).

10. $\S 12102(2)(\mathrm{A})$.

11. See, e.g., Kevin H. Smith, Disabilities, Law Schools, and Law Students: A Proactive and Holistic Approach, 32 AKRON L. Rev. 1 (1999) (discussing the numerous mental impairments that can affect law students particularly, including dyslexia). 
problem that requires him to re-read sections of his essay several times to stay on track? Should a person with an anxiety disorder, or Tourette syndrome that results in vocal tics or even obsessive compulsive disorder, be allowed to take tests in a separate setting so as to avoid possible distraction by or of others and to reduce stress and the symptoms of the student's disability? To what extent are these accommodations "reasonable," and - the other question - to what extent are they "fair?"

\section{THE LAW}

As we mentioned previously, an individual is considered disabled under the ADA if she has a "a physical or mental impairment that substantially limits one or more of the major life activities of such individual." ${ }^{2}$ Thus, to abide by the law, the first question a law school must ask is whether the student has a disability.

Courts examine whether a student has a disability under the ADA by asking three questions. First, the court must determine whether the individual has a "physical or mental" impairment. ${ }^{13}$ Second, the court must decide "whether the life activity on which the individual relies amounts to a 'major' life activity," and third, the court must determine whether the "impairment "substantially limits' that major life activity." "If an individual is found to be "substantially limited" and still meets the "essential eligibility requirements" of the relevant program, she may then seek reasonable accommodations from her employer or university. ${ }^{15}$ We will discuss each of these requirements in turn.

12. $\S 12102(2)$.

13. Bartlett v. N.Y. State Bd. of Law Exam'rs, 226 F.3d 69, 79 (2d Cir. 2000) (citing Bragdon v. Abbott, 524 U.S. 624, 631 (1998)).

14. Id. Title II of the ADA specifically defines a "qualified individual with a disability" as an individual with a disability who, with or without reasonable modifications to rules, policies, or practices, the removal of architectural, communication, or transportation barriers, or the provision of auxiliary aids and services, meets the essential eligibility requirements for the receipt of services or the participation in programs or activities provided by a public entity. $\S 12131(2)$

15. $\S 12131(2)$. It should be noted that Title II claims apply to public law schools, while Title III claims apply to private law schools. However, the application of the two is essentially identical. To read more about applicable disability law in the law school setting, see Smith, supra note 11, at 1 . This article includes a thorough treatment of disability law as applied to public and private law schools. 


\section{A. Physical or Mental Impairment in a Major Life Activity}

While the statute fails to describe what constitutes a "major life activity" in its definition of a disability, several agencies make guidelines available to the courts and universities. ${ }^{16}$ The Equal Employment Opportunity Commission (EEOC) promulgated regulations describing what could be considered a major life activity; these include "caring for oneself, performing manual tasks, walking, seeing, hearing, speaking, breathing, learning, and working." ${ }^{17}$ It should be noted, however, that this guidance is not controlling, and courts, if so choosing, could expand the definition of "major life activity." 18 However, this inquiry of whether a person has a physical or mental impairment in a major life activity is generally not an issue in law schools since learning is considered a major life activity and documentation is presented to the school based on a professional diagnosis and description of limitations in functioning based on the disability. Instead, the problem is focused on whether a person is substantially limited in such major life activity.

\section{B. Substantially Limited}

To determine whether an individual is substantially limited within the meaning of the ADA, courts, and in turn employers and universities, consider a number of factors, including "(1) the nature and severity of the [individual's] impairment, (2) the duration or expected duration of the impairment, and (3) the permanent or expected long-term impact of the impairment." ${ }^{19}$ Courts

16. The Supreme Court noted in Sutton v. United Air Lines, 527 U.S. 471, 479 (1999), that "no agency has been delegated authority to interpret the term 'disability." However, the Second Circuit noted in Bartlett that "the agency authorized to issue regulations implementing specific provisions of the ADA is entitled to 'great deference' on the meaning of 'disability' as used in those provisions." 226 F.3d at 79 (2d Cir. 2000) (citing Muller v. Costello, 187 F.3d 298, 312 \& n.5 (2d Cir. 1999) (according "great deference" to Equal Employment Opportunity Commission's interpretation of "disability" in employment discrimination case under Title I)). Because the Attorney General "has authority to issue regulations implementing Title II, the Department of Justice regulations interpreting 'disability' are entitled to great deference." Id.

17. 29 C.F.R. $\S 1630.2$ (i) (2007). Courts often look to the EEOC regulations to determine the meaning of major life activity. See Sutton v. United Air Lines, 130 F.3d 893, 900 (10th Cir. 1997).

18. See, e.g., Grevas v. Vill. of Oak Park, 235 F. Supp. 2d 868, 873-74 (N.D. Ill. 2002) (finding sleeping to be a major life activity).

19. McGuinness v. Univ. of N. Mex. Sch. of Med., 170 F.3d 974, 978 (10th Cir. 1998). Court cases determining the definition of "substantial limitation" tend to be employment discrimination claims, rather 
tend to analyze both Title II and Title III claims similarly, although the agency guidelines suggest slightly different standards for the different claims arising under the ADA. The EEOC's regulations that relate to Title $I$ in the employment setting, ${ }^{20}$ which courts sometimes use in educational settings, include considerations of the individual's geographic area and the class of broad range of jobs from which the individual has been disqualified. ${ }^{21}$ However, the agency suggests that the measure of whether a person is substantially limited focuses on the individual in question as compared to the average person in the general population. ${ }^{22}$ On the other hand, the Department of Justice (DOJ), in applying Title II, uses somewhat different terms, suggesting that the individual should be compared to "most people," rather than an average person. ${ }^{23}$ This difference is, at best, negligible.

Comparisons of law students to the average population may cause courts to determine that a person is not substantially limited. In Gonzalez v. National Board of Medical Examiners, ${ }^{24}$ the District Court for the Eastern District of Michigan addressed the issue of the proper comparison group for determining whether a medical student was substantially limited for his medical board licensing exam. The plaintiff sought accommodations on his medical board licensing exam in the form of extra time. The court determined that when considering whether the student is substantially limited, the student should be compared to the average person in the general population rather than to the

than claims regarding education facilities. Still, courts have held that the employment discrimination cases focusing on substantial limitation can be applied to the graduate school setting. See John F. Wagner, Annotation, What Constitutes Substantial Limitation on Major Life Activity of Working for Purposes of Americans with Disabilities Act, 141 A.L.R. Fed. 603 § 2(a) (1997). See also McGuinness, 170 F.3d at 978 ("The deciding principles of employment discrimination cases can be applied to ADA claims in the educational context." (citing McPherson v. Mich. High Sch. Athletic Ass'n, Inc., 119 F.3d 453, 460 (6th Cir. 1997))).

20. 29 C.F.R. $\S 1630.2(\mathrm{j})(2007)$.

21. Id. $\S 1630.2(\mathrm{j})(3)(\mathrm{ii})$.

22. Id. § $1630.2(\mathrm{j})(1)(\mathrm{i}-\mathrm{ii})$. Substantially limited means:

(i) Unable to perform a major life activity that the average person in the general population can perform; or

(ii) Significantly restricted as to the condition, manner or duration under which an individual can perform a particular major life activity as compared to the condition, manner, or duration under which the average person in the general population can perform that same major life Id. activity.

23. 28 C.F.R. pt. 35, app. A (2007) ("A person is considered an individual with a disability for purposes of Test A, the first prong of the definition, when the individual's important life activities are restricted as to the conditions, manner, or duration under which they can be performed in comparison to most people.").

24. 60 F. Supp. 2d 703 (E.D. Mich. 1999), aff'd, 225 F.3d 620 (6th Cir. 2000). 
performance of others with a similar age and education. ${ }^{25}$ A similar comparison was examined in both Price v. National Board of Medical Examiners $^{26}$ (Southern District of West Virginia) and Bartlett v. New York State Board of Law Examiners ${ }^{27}$ (Second Circuit). Rather than determining whether the student is substantially limited with regard to other students in the class, the student is compared to people in the general population. Susan Stefan suggests that this comparison with the population as a whole, rather than with other law students, "means that students with learning disabilities, who could successfully compete . . . with reasonable accommodations, are excluded from both education and career opportunities in law." ${ }^{28}$

When considering whether an impairment "substantially limits" one or more major life activities, courts also consider "the extent of the impairment with reference to mitigating or corrective measures, such as medicines and assistive or prosthetic devices." ${ }^{29}$ However, this use of corrective devices "does not, by itself, relieve one's disability," nor does it end the court's inquiry as to the disability. ${ }^{30}$ Still, it is feasible that mitigating or corrective measures can prevent an individual from qualifying under the ADA. Thus, if a person can mitigate their ADHD with medication, she may not qualify under the ADA.

If an individual requests reasonable accommodations due to a learning disability in accordance with the ADA, the university will classify that student as disabled if he demonstrates he meets the aforementioned criteria. ${ }^{31} \mathrm{~A}$ university may require that the student "provide current documentation from a qualified professional concerning his learning disability." 32 While many universities require current documentation for a student to assert that she is qualified as disabled under the ADA, for the most part these cases are determined between the university and the student without legal intervention.

\footnotetext{
25. Id. at 709 .

26. 966 F. Supp. 419, 425 n.2 (S.D. W. Va. 1997).

27. 226 F.3d 69, 80 (2d Cir. 2000).

28. Susan Stefan, Unequal Rights: Discrimination Against People with Mental Disabilities and the AMERicans with Disabilities ACt 314 (2001).

29. Levy, supra note 5, at 93; see also Sutton v. United Air Lines, Inc., 527 U.S. 471, 488 (1999); Bartlett, 226 F.3d at 80.

30. Bartlett, 226 F.3d at 80 (citing Sutton, 527 U.S. at 488).

31. See Amir v. St. Louis Univ., 184 F.3d 1017, 1027 (8th Cir. 1999); see also 42 U.S.C. $\S 12102(2)(2000)$.

32. Guckenberger v. Boston Univ., 974 F. Supp. 106, 135 (D. Mass. 1997) (citing Halasz v. Univ. of New England, 816 F. Supp. 37, 46 (D. Me. 1993) ("When a university operates a program specifically for the handicapped, it clearly needs to know about an applicant's handicaps before it can make a decision about admission to the program.")).
} 


\section{Reasonable Accommodations}

If an individual is classified as disabled, then schools must make "reasonable accommodations" to account for that disability. ${ }^{33}$ The ADA defines reasonable accommodations as:

(A) making existing facilities used by employees readily accessible to and usable by individuals with disabilities; and

(B) job restructuring, part-time or modified work schedules, reassignment to a vacant position, acquisition or modification of equipment or devices, appropriate adjustment or modifications of examinations, training materials or policies, the provision of qualified readers or interpreters, and other similar accommodations for individuals with disabilities. ${ }^{34}$

Providing reasonable accommodations does not mean that a school should "make fundamental or substantial modifications to its programs or standards." ${ }^{35}$ For instance, a law school need not allow a student with a writing disability to have the school's legal research and writing requirement waived. Instead, a school must make "fact-specific, individualized analysis of the disabled individual's circumstances and the accommodations that might allow him or her to meet the program's standards." ${ }^{36}$ The school will receive deference for its academic decisions, as "[courts] should show great respect for the faculty's professional judgment."

Moreover, reasonable accommodations must not place an undue burden on the school itself. ${ }^{38}$ Yet again, this test is ambiguous: what is an undue burden in the context of mental impairments? Surely providing a separate room in which a student has extra time to complete an in-class exam could not be considered an undue burden. It is difficult to think of a scenario where accommodations for learning disabilities will be considered an undue burden on a law school.

33. § 12111(9).

34. Id.

35. 14 C.J.S. Civil Rights $§ 163$ (2007); see also Se. Comm. Coll. v. Davis, 442 U.S. 397, 413 (1979). In Davis, the Supreme Court held that "[The Rehabilitation Act] imposes no requirement upon an educational institution to lower or to effect substantial modifications." Id. While this Article concerns the $\mathrm{ADA}$, courts interchange the requirements of the ADA and the Rehabilitation Act.

36. 14 C.J.S. Civil Rights $\S 163$ (2007).

37. Amir v. St. Louis Univ., 184 F.3d 1017, 1029 (8th Cir. 1999) (citing Regents of Univ. of Mich. v. Ewing, 474 U.S. 214, 225 (1985)).

38. See $\S 12111(10)(\mathrm{B})$. 


\section{Interpretation}

In law schools, reasonable accommodations for learning disabilities most often include extra time on tests ${ }^{39}$ but may also include providing class notes and recorded lectures, dividing a test into segments, and allowing a separate setting for an examination. This list is of course not exhaustive.

Some commentators suggest that law schools "should interpret expansively both 'disability' and 'reasonable accommodations," disabled students access to a variety of accommodations and services. This argument is based on the theory that law schools and their faculties should "work actively to develop fully all students' skills and abilities."

Moreover, schools are free to accommodate disabilities that may not be "qualifying" disabilities under the ADA, and many often do. The ambiguities make accommodating a student a "safer path," preventing a lawsuit in federal court.

\section{Application of the Law: Who is Disabled?}

An analysis of particular students seeking accommodations in law school illustrates the difficulty in applying the ADA. Law addresses problems of people, providing a path through example to determine a just outcome. Martha Fineman's important work on narrative in the law introduces a casestudy perspective in keeping with approaches used by psychologists. ${ }^{42}$ It feels familiar and intimate. Narratives present the data that can be sifted through by individuals trained in different disciplines, allowing various methods of analysis and understanding based on different methods of inquiry. ${ }^{43}$ The story of an individual becomes richer when important information is connected in narrative form. Professor Fineman notes that both interdisciplinarity and the addition of "concrete perspectives" address "the law's capacity to exclude and marginalize those most in need of justice." ${ }^{\prime 4}$ Though intended to apply to her work in feminism and the law, we can easily transfer this perspective to an inspection of the implications of the law that applies to individuals with

\footnotetext{
39. See Ruth Colker, Extra Time as an Accommodation, 69 U. Piтt L. Rev. 413 (2008).

40. Smith, supra note 11 , at 3 .

41. Id. at 4 .

42. Martha Albertson Fineman, Storytelling and the Law: Narrative, Ethics, and Legal Change,

7 Emory Across Academe 3 (2007).

43. Id.

44. Id
} 
disabilities. These individuals are often known through documents with facts and numbers that are decontexualized. The complexity of the individual should be understood in order to apply the law towards the goal that was intended.

Two students, Benjamin and Allison, ${ }^{45}$ both of whom had initial difficulties learning, are described below, as they possess typical histories and symptoms of individuals with non-visible disabilities who would successfully gain entrance to a graduate or professional program, such as law. These cases are composites based on many individuals who experience mild problems that have the potential to cause major difficulties when the individuals are confronted with tasks that emphasize their areas of weakness rather than their strengths. Many who teach have had students like Benjamin and Allison in their classes, perhaps without knowing the stress that these students experience in certain academic situations. These students often have compensated for their difficulties to a large extent but have not overcome them. The residual deficits make learning more difficult, but they experience success with appropriate accommodations.

\section{Benjamin}

Benjamin was precocious in his language development and his exploratory powers from his earliest years. He amazed his teachers with his ability to put together puzzles, build complex structures with blocks, and perform math calculations in his head. He avoided drawing, writing, or anything that required him to follow lines, like connecting the dots or mazes that entertain others his age. Midway through first grade, his parents were informed by his teacher that Benjamin refused to write or draw and he was not learning to read basic sight words. This started a series of interventions, first by the teacher and parents and later with tutors and occupational therapists. In second grade, he was evaluated and his parents were told he had a superior intellect, but there were learning disabilities in reading and writing based on findings of visual processing problems. With intervention, Ben learned to read when he was in third grade. He was a slow but effective reader who used reading to gain knowledge on his own. As he got older, he especially loved to read about history, particularly about the Civil War, which he and his father explored together. Benjamin's handwriting was very difficult to read, but he

45. The names and cases described through these two characters are fictional although intended to be representative of the difficulties some students face. 
compensated for his scrawl by his strength in memory. Ben avoided math homework and writing compositions, procrastinating as long as he could. Once he sat down to do his work, he worked slowly, but he demonstrated his conceptual knowledge in his written work, impressing his teachers by the complexity of his ideas and his understanding of abstract relationships.

Benjamin turned to the computer for writing in middle school, and based on a new evaluation, it was recommended that he be granted extra time on tests because of his lack of fluency in reading and written expression. He later became a very successful student in high school, needing accommodations on tests only infrequently, but he worked longer hours than his peers to keep up with the greater amounts of reading and writing required in the advanced courses in which he was placed. He was admitted to a competitive college.

Ben struggled during his first year with the amount of reading and writing that was required. He accepted that he would study long hours evenings and weekends. A professor noted his enthusiasm for modern Southern history; they shared common interests and became intellectual colleagues. Ben wrote an exceptional honor's thesis that earned him a department award, and he graduated summa cum laude.

Benjamin applied to law school, taking his LSATs with extended time based on the recommendation in a new evaluation and was accepted at his top choice. He asked for extended time on his tests. His record was reviewed. The question arose as to whether this should be granted. All his grades in college had been excellent. He had rarely used accommodations his last years in college because most of his higher-level courses required papers, which he completed outside of class, taking his time. His scores showed that all his academic skills were developed as well as the average individual his age, although his reading was still painfully slow and his writing scores-when unaided by computer - were well below his superior intellectual abilities. He continued to meet diagnostic criteria for learning disabilities in reading and writing, but none of his scores were considered below those of the "average" individual.

A number of issues remain to be determined by a law school. Should it grant accommodations based on Ben's history? Should he be considered to be significantly limited based on the skills of most others in law school, or should he be compared to the average individual? How much extended time for reading and writing, if any, should he be granted? Who should make the determination? Should the accommodation be noted on his transcript? 
Allison

Allie was born energetic. She walked at nine months and ran at two years. She was an explorer who cruised every new setting, touching everything in sight. As she matured, Allie's parents found that if they did not keep her busy, she would get into trouble, trying new things without fear of consequences. Allie talked early and constantly, asking many questions and coming up with weird and wild explanations for things from her imagination. Allie was an exciting but exhausting child to her parents.

When Allie learned to read at age four, she and her parents were delighted. She devoured books in one sitting, immersed in the new fictional and non-fictional worlds. By contrast, once she entered elementary school, she had great difficulty listening in class, staying seated, and learning basic math facts, even though she understood mathematical concepts. Allie's grades were highly variable. It was first assumed that Allie would outgrow these problems, but she continued to have difficulty focusing on group instruction and her papers were often rushed and incomplete. She had trouble finding her assignments in the chaos of her book bag. She procrastinated on all written homework. Homework time became a nightmare for both Allie and her parents.

By the fifth grade, Allie was referred for an evaluation and diagnosed with Attention Deficit Hyperactivity Disorder Combined Type based on the manifestation of difficulty managing her attention, impulsivity, and deficits in other self-regulatory behaviors. She was found to have very superior intellectual abilities but a low average working memory score. Once stimulant medication was introduced, she was better able to meet teachers' expectations and to organize her work. Allie's parents learned to provide her with structure and support.

In high school, Allie took Latin based on a suggestion of the psychologist who noted that her working memory weakness might result in her having difficulty mastering a foreign language. She studied Latin and loved it. She excelled in English and won a poetry competition. She was very involved in track and ran competitively with great success.

With the continued use of medication and parental structure and support, Allie's grades were excellent in high school and she scored a perfect 800 on her verbal SATs, which she took with extended time and separate-setting accommodations. She was admitted to an Ivy League college where she continued to participate in track, and where she was considered to be one of the most competitive runners. She double-majored in Latin and English and used accommodations only for in-class tests. When she applied to take the 
LSAT, she was granted accommodations based on her history of accommodation and documentation.

Allie applied to several law schools and was admitted to all. She did not ask for accommodations because she worried about their potential effect on future employment. She found the discussions in class energizing, loved to engage with other students on points of law, but found herself falling behind in her classes. Her organization and note-taking skills were poor. Still, she impressed her teachers with her grasp of concepts. They could not understand why she did not do better on tests. Her thoughts were disorganized and she tended not to get to the point when writing tests in class. Her papers, however, were excellent. Allie's documentation recommended, based on history and assessment results, that she be allowed to take tests apart from the other students, use a computer, take breaks "to collect her thoughts," and be allowed extended time for planning and editing her work based on her attention deficit disorder.

The dean reviewed the documents. They showed a history of disability and use of accommodations as well as continued need for medication based on processing weaknesses, but there were no areas in which she performed below the average individual of her age. Should she be allowed to take tests in ways her documentation described? Did that offer her an "unfair advantage?" Should she be allowed to receive notes from another student?

\section{A. Dilemmas}

\section{Who is disabled?}

These cases present dilemmas for those who consider the application of the ADA within a competitive professional school. Keeping in mind that the original purpose of allowing accommodations is to provide individuals with disabilities access to programs, services, and environments similar to those provided to others, ${ }^{46}$ the first dilemma is to determine the comparison group. Which others? Should the comparison be to the "average" individual in the population, or to "most others," as in Gonzalez, Price, and Bartlett ${ }^{47}$ That is, should the standard be set so that a measurable deficit relative to "most others" is the deciding factor, or should the comparison be to the peer group, thereby considering relative weaknesses - functional levels compared to what

46. See supra note 4.

47. See supra notes 24-27 and accompanying text. 
most law students can do? Courts, after examining the purpose behind the ADA, tend to focus on the average individual within the general population rather than the specific law school population. Should this distinction really matter? Considering that most accommodation issues do not intersect with the legal system, should schools relax their standards to allow more than what the law itself would require, instead finding those disabled who, when compared to their peer group, may merely be weaker in some abilities? Is the purpose of the ADA to provide an absolute baseline or to allow equal access in the context of the environment in which this "otherwise qualified" individual must perform?

\section{What is essential?}

Because the ADA preserves academic standards and seeks to avoid changing the requirements of a program, it is important for the essential elements of the legal curriculum to be defined. This presents the second dilemma: how to determine what is "essential" in a law school curriculum. Many scholars would agree that legal analysis and writing are essential to the law school curriculum. Law school orientations inevitably begin with the presentation that not only will students learn the law, but they will "learn how to think like a lawyer." ${ }^{48}$ In law school, students learn more than merely black letter law. Students learn, among other things, how to "analyze the structure of argument and language itself [and] how the law is constructed or destroyed through the manipulation of language." ${ }^{49}$ They further learn how to write a case brief- "reducing" a case to its essence by listing the case's facts, procedural posture, the issue the court faces, and the court's holding. ${ }^{50}$ They also learn case synthesis - in legal writing, legal methods, or a class in a substantive area of law, such as administrative law-where students "derive a single rule of law" from a line of cases that may appear to have separate

48. A number of commentators have addressed the issue of thinking like a lawyer. See, e.g., Paul Bateman, Toward Diversity in Teaching Methods in Law Schools: Five Suggestions from the Back Row, 17 QuinniPIAC L. Rev. 397, 401 n.14 (1997); Jack T. Camp, Thoughts on Professionalism in the TwentyFirst Century, 81 Tul. L. Rev. 1377, 1394 (2007); David R. Culp, Law School: A Mortuary for Poets and Moral Reason, 16 Campbell L. Rev. 61, 78 (1994); Richard F. Devlin, Legal Education as Political Consciousness-Raising or Paving the Road to Hell, 39 J. Legal Educ. 213, 216 n.18 (1989).

49. Adam Todd, Neither Dead nor Dangerous: Postmodernism and the Teaching of Legal Writing, 58 BAYLOR L. REV. 893, 940 (2006).

50. Deborah A. Schmedemann \& Christina L. KunZ, Synthesis: Legal Reading, Reasoning, AND WRITING 32-33 (1999). 
holdings. ${ }^{51}$ Still, while much of law school is focused on learning how to think and read critically while exploring different legal theories, most law schools' professors base their class grades on one final exam that is often taken in the classroom with a limit of time, often three hours.

Considering all that is contained within the purview of a legal education, does extended time, the most common form of accommodation for individuals with non-visible disabilities, ${ }^{52}$ affect what is an essential element of the professional development of lawyers?

Some may argue that speed and thoroughness in analysis is essential in the career of a lawyer because "billable hours" must be efficient hours, while others consider speed of processing to be beneficial but not essential. Also at issue is the primary role of a law school - to train lawyers, or to train thinkers? An academy or a professional school? An individual need not practice law in a traditional law firm to find a law degree applicable. The legal education is useful in a variety of fields, from public policy analysis to basic business fundamentals. "The term 'essential' serves to ensure that colleges and universities need never 'fundamentally alter' their programs of instruction to accommodate students with disabilities." ${ }_{33}$ However, a law school must determine what is essential to assess whether it is fundamentally altering its programs.

\section{What are "reasonable" accommodations?}

Determining the right match between the disability and the accommodation is another dilemma. Does providing an accommodation, such as specialized technologies or changes in testing conditions, change the nature of the program or prevent the student from developing coping strategies? Issues of "fairness" are raised when a student is granted an accommodation for a purpose that is not readily apparent. In the high pressure cauldron that can be law school, the concern exists that a student with an accommodation will receive a benefit that will allow an advantage not given to others, thus affecting the curve and potential job prospects.

This raises the question of test validity-will a test taken with an accommodation be as valid a measure of what it is intended to measure as one

51. See Todd, supra note 49, at 937.

52. Stefan, supra note 28, at 321.

53. Paul D. Grossman, Making Accommodations: The Legal World of Students with Disabilities, ACADEME ONLINE, Nov.-Dec. 2001, http://www.aaup.org/AAUP/pubsres/academe/2001/ND/Feat/ gross.htm. 
without an accommodation? Those who develop tests recognize that even the best constructed tests measure two things: what is intended to be measured (the validity) and what is not intended (the error). ${ }^{54}$ Every test has some uncontrolled error despite the efforts to minimize this through careful test construction and administration practices.

Although tests attempt to measure only pertinent knowledge and reasoning skills, in fact, every test also measures error caused by external and internal factors, such as distracting noises, uncomfortable room climate, anxiety, headaches, etc. For individuals with disabilities that are not accommodated, the error level rises while the validity decreases. Therefore, the accommodation is meant to increase validity by allowing the student to overcome a known source of error and allow the test to measure what it is intended to measure.

Some raise concerns about "learned helplessness," the degree to which a student becomes "disabled" by over-accommodation. Do accommodations promote dependency, create accessibility, or both? To a great extent, it is up to the student to develop professional skills that meet the standards of the program and workplace.

What about law students who are continually provided accommodations during law school but then are unable to receive accommodations for the bar exam? ${ }^{55}$ There are two issues of relevance: one pertains to our knowledge of how individuals learn as informed by neuroscience, and the other relates to criteria for receiving accommodations on the bar exam as informed by policy.

What we understand about learners is that the more they practice a new skill, the more efficient and effective they become in that skill. ${ }^{56}$ Law students have selected this field and have been selected by their programs because law emphasizes their cognitive and personal strengths. Guided and then independent practice in skill development allows the novice to become an expert over time. Is it the responsibility of law programs to develop internal and external resources that will promote this process of change, or is it the student's? To what extent should promoting this adaptive capacity be part of the instructional objectives of a professional law program? Of course, to

54. Measurement error may be divided into random (no consistent effects across the group) and systematic (consistent effects) error. See William M. Trochim \& James P. Donnelly, Research Methods Knowledge Base (3d. ed. 2006), available at http://www.socialresearchmethods.net/ $\mathrm{kb} /$ measerr.php.

55. See, e.g., supra notes 24-27.

56. For information about how experts differ from novices, see NAT'L RESEARCH COUNCIL, How People Learn: Brain, Mind, Experience, and School 19-38 (John D. Bransford et al. eds., 1999). 
answer these questions, one must also ask what skills should a law school be teaching prospective lawyers generally?

Title III of the ADA states that "any person that offers examinations ... related to ... licensing ... for [ ] professional ... purposes shall offer such examinations in a place and manner accessible to persons with disabilities." ${ }^{57}$ The applicable DOJ regulations, however, narrowly define disabilities as those that "impair sensory, manual[,] or speaking skills" so that psychiatric, attention, and learning disabilities are excluded.$^{58}$ Questions have been raised as to the validity of these restrictions. ${ }^{59}$

What are the issues associated with increased diversity of law school students?

Many law programs seek to admit students who represent the diversity in the population in general. Demographic diversity is accompanied by differences in preparation, learning styles, personal habits, expectations, and abilities. Considerable conversation exists in graduate schools about the characteristics of the millennial students in general who arrive comfortable with technology and less used to using traditional print resources. ${ }^{60}$ These generational issues compound the intra-individual diversity that is the norm.

Millennial students expect to participate in electronic access to information and to use electronic tools in their academic programs; they are consumers of educational services; their expectations of faculty are high. Exposed throughout their educational experiences to visual and auditory stimulation from diverse sources, ${ }^{61}$ they expect learning to be multimodal and to communicate in diverse ways. These millennial students employ many of the same technologies and use similar resources as students with mild disabilities. In many regards, the gap between the "regular" learner and the "disabled" learner becomes less obvious.

57. 42 U.S.C. $\S 12189$ (2000).

58. See Stefan, supra note 28, at 329 n.172.

59. See id. (discussing relevant litigation regarding these regulations).

60. See Diane Oblinger, Boomers, Gen-Xers and Millennials: Understanding the New Students, Educause Review, July-Aug. 2003, at 37-39, available at http://www.educause.edu/ir/library/pdf/ erm0342.pdf.

61. See generally id. Born into a world of technology, modern students depend on such technology and feel comfortable multi-tasking. Professor Oblinger discusses the implications of the learning preferences of Millennials for teaching in colleges and universities. 


\section{Diversity, Disability, and Instructional Design}

Applying Universal Design (UD) principles to law school instruction could reduce the need for accommodations for law students and thus promote effective learning and assessment of learning. Originally, the intention of UD was to develop products and environments that would be "usable by all people, to the greatest extent possible, without the need for adaptation or specialized design." ${ }^{62}$ We all take advantage of these "universally-designed" features in our environment - for example, using curb cuts if we are wheeling a suitcase, reading captions on televisions, and enjoying the ease of a lever door handle when we carry packages. We do not need these features all the time, but they solve problems for us when we do need them.

The principles of UD were adopted and applied to teaching by the educational community. ${ }^{63}$ This work has promoted instructional practices that provide access of instruction to a wide range of learners, including those with disabilities. The Universal Design to Instruction (UDI) paradigm promotes equitable use, flexibility, easily accessible information, and increased tolerance for errors, among other features. ${ }^{64}$ According to these principles of UDI, a take-home test would be more flexible, tolerant of error, and equitable than an in-class exam with its strict time limits because it allows students to plan, write, and self-evaluate their work within time frames that suit their needs. ${ }^{65}$ Web materials would be designed to be accessible to individuals with visual impairments and reading disabilities through the use of a screen reader, and tags would be attached to each graphic so that images would be explained verbally for students with visual impairments.

Experts working with the Center for Universal Design established seven principles for the universal design of any product or environment. ${ }^{66}$ These principles are listed, each matched with a guideline and an example of its application to an educational product or environment.

62. Bettye Rose Connell et al., The Principles of Universal Design (1997), http://www.design.ncsu .edu/cud/about_ud/udprinciplestext.htm.

63. Joan M. McGuire et al., Universal Design and Its Applications in Educational Environments, 27 Remedial \& Special Educ. 166, 170 (2006).

64. See Connell et al., supra note 62 .

65. Take-home tests may also raise other issues that need to be controlled, such as excessive writing or sharing of information, so specifications may need to be attached to make this an attractive alternative for assessment.

66. Connell et al., supra note 62 . 
- Equitable Use. "The design is useful and marketable to people with diverse abilities." ${ }^{\circ 7}$ An example of this principle in application is museum information provided in several languages commonly used in the community, thus making the environment welcoming and inclusive.

- Flexibility in Use. "The design accommodates a wide range of individual preferences and abilities." ${ }^{68}$ This principle in application is an instructor who provides multiple ways for faculty and students to interact.

- Simple and Intuitive. "Use of the design is easy to understand, regardless of the user's experience, knowledge, language skills, or current concentration level." ${ }^{\prime 69}$ Software that gives clear, intuitive directions for use employs this principle.

- Perceptible Information. "The design communicates necessary information effectively to the user, regardless of ambient conditions or the user's sensory abilities. ${ }^{\prime 70}$ An example of this principle is captions provided in videos.

- Tolerance for Error. "The design minimizes hazards and the adverse consequences of accidental or unintended actions." ${ }^{71}$ Software that gives guidance when an error is made is an application of this principle.

- Low Physical Effort. "The design can be used efficiently and comfortably and with a minimum of fatigue." 72 This principle is applied in lab equipment that is easy to operate.

- Size and Space for Approach and Use. "Appropriate size and space is provided for approach, reach, manipulation, and use regardless of [the] user's body size, posture, or mobility." ${ }^{73}$ Lab equipment that is usable by students with a wide range of physical characteristics utilizes this principle.

The Center for Applied Special Technology (CAST) defined the core principles of instruction that would be accessible to the widest range of learners:

- Multiple means of representation to give learners various ways of acquiring information and knowledge,

- Multiple means of action and expression to provide learners alternatives for demonstrating what they know, and

- Multiple means of engagement to tap into learners' interests, challenge them appropriately, and motivate them to learn. ${ }^{74}$

Matching these core characteristics of accessible instructional practices with those used in law school classrooms would be a useful first step in
67. Id.
68. Id.
69. Id.
70. Id.
71. $I d$.
72. Id.
73. Id.
74. CAST: What is Universal Design for Learning?, http://www.cast.org/research/udl/index.html (last visited Aug. 15, 2008). 
determining the extent to which these practices promote or deny access to diverse learners.

Law has some inherent advantages over others types of academic content: it presents information in narrative form, making it memorable through its context; it is readily applicable, creating interest and motivation; its research base is searchable through online resources; and it is active in requiring student participation. On the other hand, law studies require extensive amounts of reading and writing; the style of writing is not intuitive; anxiety is increased when students are called on spontaneously; and memory is taxed by the need for rapid retrieval of detailed and complex information. The question then becomes how to draw on the strengths of the material by presenting it in a manner that promotes learning, stimulates interest and not anxiety, then promotes collaboration of students to support each others' learning and allows students to demonstrate their mastery.

The traditional law school classroom brings to mind the scene with Professor Kingsfield's contracts class in the classic law school movie, the Paper Chase, ${ }^{75}$ where the professor calls on students in class, asking them to answer specific questions about the contracts cases they read for the previous night's assignment. While many law professors still use the Socratic method to teach the class ${ }^{76}$ often cold-calling on students in what seems to be a random fashion, alternative teaching methods being used in legal classrooms today include "small groups, role playing, ... writing projects, videos, guest lecturers, simulations, and discussions." popular Law and Order franchise are used to illustrate criminal procedure practices in criminal law classes. Professors also employ, for instance, response papers and group-project client letters in professional responsibility and legal writing classes.

We do not suggest that law professors abandon the Socratic method as they teach - the Socratic method advances critical thinking skills. ${ }^{78}$ However,

75. The Paper Chase (Twentieth Century Fox 1973); see also Michael Vitiello, Professor Kingsfield: The Most Misunderstood Character in Literature, 33 Hofstra L. Rev. 955 (2005)(discussing the Socratic method at length).

76. For a discussion on the purpose and criticism of the Socratic method, see Bateman, supra note 48 , at $403-05$.

77. Id. at 399 .

78. See James B. Levy, As a Last Resort, Ask the Students: What They Say Makes Someone an Effective Law Teacher, 58 ME. L. REv. 49, 70 (2006) (noting that studies have shown that the Socratic method works in non-law school contexts). 
this method has its share of detractors, including those who argue that it makes some students feel uncomfortable, overlooked, or anxious. ${ }^{79}$

Other teaching techniques can "supplement" the Socratic method to have students both better understand the Socratic method and to participate more in the classroom. ${ }^{80}$ Writing assignments evaluated throughout the semester could also reduce anxiety as one assessment would not be the basis for the entire class grade and multiple assignments with feedback would allow students to improve in defined aspects of their output. Moreover, these writing assignments teach students "the importance of detail and precision in law practice." ${ }^{\prime 1}$ These types of assignments allow the professor to focus on different points for evaluation, rather than how much analysis a student can produce during a three-hour exam. Furthermore, the movement away from only using the Socratic method allows students with other types of learning styles more opportunity to succeed. ${ }^{82}$

Some professors already integrate technology into their classrooms, providing students with PowerPoint presentations and outlines for classes as they proceed through the traditional lecture and question-and-answer law school form. Others use case studies or hypotheticals in their presentations. Law schools can continue to provide support and encourage professors to diversify their pedagogical practices so that instruction is more accessible to the diverse learners who are entering their schools.

What should be done about the profession and academy's "but that is how we learned" attitude, which may cause reluctance to introduce different teaching styles? Ultimately, the goal of law schools is to create a group of individuals who are professionally trained in all aspects of the law and have the analytic tools to serve the multiple legal needs of American society. Medical schools were forced to reevaluate the pressures and schedules that residents faced because data showed people were becoming injured. Although the consequences may not be so immediate or dire, law schools face similar challenges, which are reflective of the challenges of a changing society in general.

79. Bateman, supra note 48 , at 407.

80. See id. at 411 .

81. Id. at 417 (citing Kathleen S. Bean, Writing Assignments in Law School Classes, 37 J. LegAL EDuc. 276, 284 (1987)).

82. See Paula Lustbader, Construction Sites, Building Types, and Bridging Gaps: A Cognitive Theory of the Learning Progression of Law Students, 33 Willamette L. Rev. 315, 324 n. 17 (1997). 


\section{Conclusion}

Neither psychology nor law can answer definitively the question of who is disabled under the ADA when addressing the complex and varying degrees of deficit and functional capacities of those with disabilities related to learning, attention, and emotional functioning - the non-visible disabilities. Psychologists who evaluate cognitive abilities, emotional functioning, and educational skills operate under a medical model that evaluates functional capacity (or "dysfunctionality") using measures that are standardized or defined clinical procedures but not standard measures that are absolutely replicable. They rely primarily on history and on relative positions on IQ, memory, and achievement tests that employ norm-referenced comparisons to determine if there are learning disabilities. Similarly, a diagnosis of attention deficit relies on reported history, cognitive measures, rating scales, and observations that rank an individual compared to others of similar age. Emotional functioning is a clinical diagnosis - relativistic and subjective. Meeting the diagnostic criteria for these disorders does not correspond necessarily to inclusion in the category of "significantly limited" in the major life activity of learning in the same way that one can accept that someone with a hearing impairment or mobility impairment is disabled based on observable and measurable data. We see someone with a hearing aid or a wheelchair, and we accept that the individual is disabled. We would readily accept that the individual would be granted an accommodation under the ADA. Dealing with individuals with psychiatric problems is even more complex because of the greater stigma attached to these disorders and the uneven path these disorders take in response to both internal and external factors.

Adding to the complications is the lack of consistency in how the courts have acted on the law, how they have varied in determining if the limitation caused by the disability is "significant" based on the comparison group (peers, "most people," or "average person"), and how professional schools have developed different standards and methods for determining who is eligible for an accommodation and how the accommodation will be delivered.

It would seem logical, therefore, to find a manner in which the instructional goals of the professional education in law could be delivered to adapt to the differences among learners rather than rely exclusively on the learners, who may have limited adaptive capacities, to adjust to historically practiced pedagogical methodologies. We do not suggest that law students should not be faced with challenges as they learn new skills and new ways of 
analysis. Indeed, it is exactly for this purpose that the instructional methods should be varied without any relaxation of standards.

The challenge that all post-secondary institutions face as they build diversity in their student bodies is that as diversity increases, we expect that the variability among learners will increase as well. This is certainly also true for individuals with non-visible disabilities who until now have relied on accommodations to address their learning needs.

UD instructional practices allow students more flexibility to use their unique capacities by providing them with opportunities to match their learning needs and styles with instructional goals. Inclusive instruction, however-the instruction that employs these principles - although intuitively beneficial, has not been adopted and evaluated for its use in law schools. Those who report its benefits anecdotally influence others to try a different type of instructional approach and word spreads. The effectiveness has generally been judged subjectively.

Although we can intuitively accept that addressing the learning differences of students by diversifying instructional methods will create a beneficial climate for learning, there is no current evidence to support this hypothesis for law schools. It is a hypothesis that has not been tested. As a psychologist trained in the intersection between learning and instruction, and a former law student, we suggest that it will be important to evaluate teaching practices and learner outcomes in the context of this new model in the realworld environment of law schools. Without careful evaluation, the principles of UDI are just principles and not validated practices that will lead to effective and inclusive instruction. 